
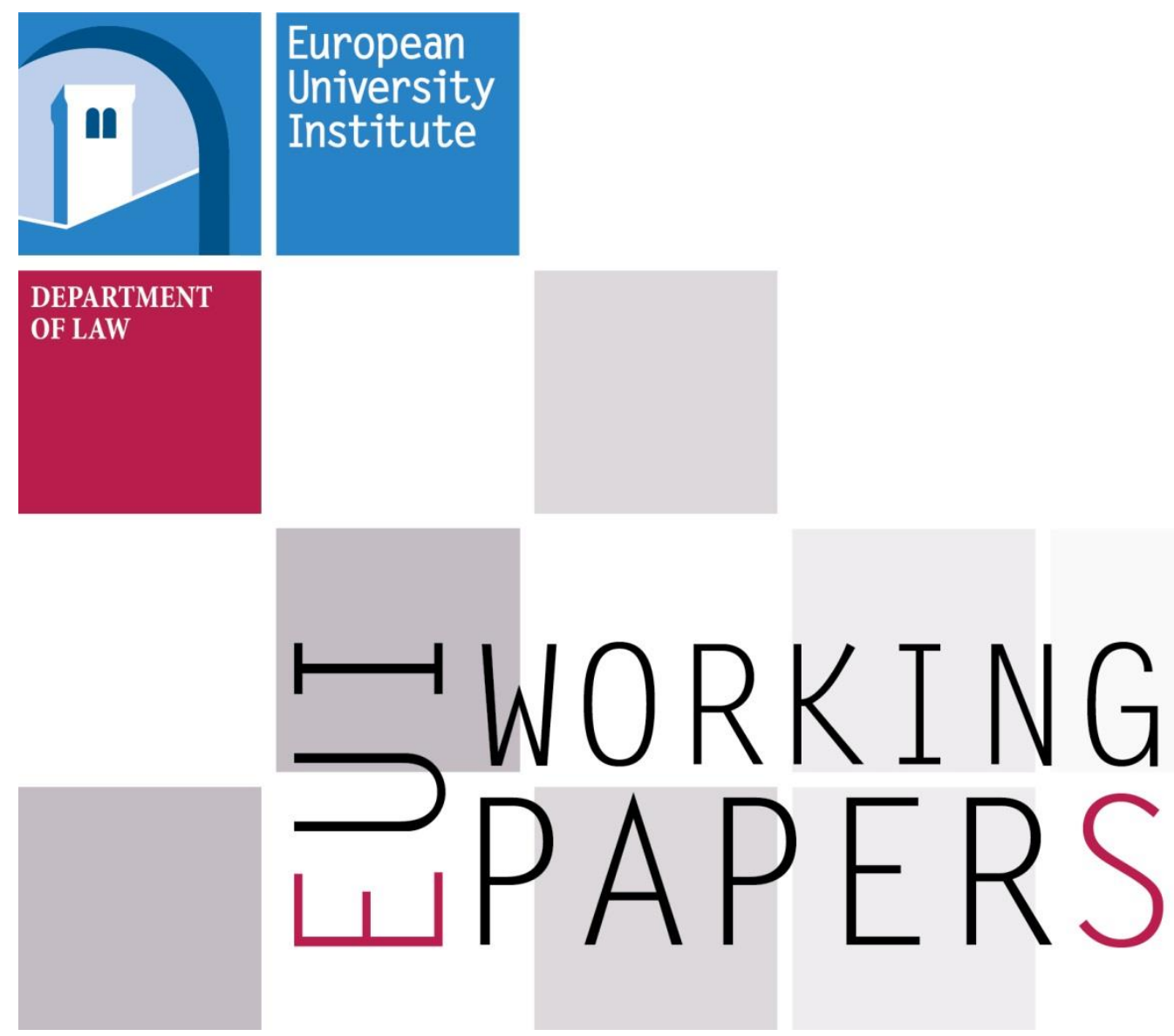

LAW 2020/01

Department of Law

German and European ordo-liberalism and constitutionalism in the post-war development of international economic law

Ernst-Ulrich Petersmann 

European University Institute

Department of Law

\section{GERMAN AND EUROPEAN ORDO-LIBERALISM AND \\ Constitutionalism in the Post-War DeVelopment of INTERNATIONAL ECONOMIC LAW}

Ernst-Ulrich Petersmann

EUI Working Paper LAW 2020/01 
This text may be downloaded for personal research purposes only. Any additional reproduction for other purposes, whether in hard copy or electronically, requires the consent of the author, editor. If cited or quoted, reference should be made to the full name of the author, editor, the title, the working paper or other series, the year, and the publisher.

ISSN 1725-6739

(C) Ernst-Ulrich Petersmann, 2020

Printed in Italy

European University Institute

Badia Fiesolana

I-50014 San Domenico di Fiesole (FI)

Italy

www.eui.eu

cadmus.eui.eu 


\begin{abstract}
This contribution discusses the regulatory approaches of German-speaking countries to the design of European and international economic law since World War II. The US initiatives for the 1944 Bretton Woods Agreements and the 1947 General Agreement on Tariffs and Trade were driven by neo-liberal, multilateral approaches prioritizing rules-based liberalization of market access barriers, deregulation, privatization and 'financialization' of markets as spontaneous information, coordination and sanctioning mechanisms enabling private economic actors to pursue their economic self-interests. By contrast, the post-war German and European ordo-liberalism and the 'Virginia School' of 'law and economics' perceived markets as legal constructs, which cannot maximize general consumer welfare without legal limitations of 'market failures', 'governance failures' and 'constitutional failures'. The federalism and constitutional protection of common market freedoms inside Austria, Germany and Switzerland contributed to their promotion of ordo-liberal, constitutional approaches also in their external economic policies aimed at creating and progressively developing Europe's micro-economic 'common market constitution' not only inside the European Union, but also in the broader 'European Economic Area', the European Free Trade Area and the EU's common commercial policies. The worldwide WTO legal and dispute settlement system was influenced both by neo-liberal US initiatives as well as by ordoliberal European proposals (e.g. for the design of the WTO dispute settlement system). The current US assault on the WTO Appellate Body system is driven by neo-liberal interest group politics and hegemonic mercantilism by the US Trump administration
\end{abstract}

\title{
Keywords
}

economic constitutionalism; international economic law; law and economics; ordo-liberalism; neoliberalism; EU law, WTO law 
Author contact details:

Ernst-Ulrich Petersmann

Emeritus Professor of International and European Law

European University Institute

Ulrich.Petersmann@eui.eu 


\section{Table of contents}

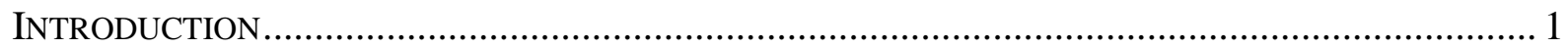

COMPETING CONCEPTIONS OF INTERNATIONAL ECONOMIC LAW …........................................ 3

From Constitutionalism 1.0 to Constitutionalism 3.0 in European Integration................................... 4

Homo Economicus: Competing Actors Prioritize Competing Self-Interests ..................................... 5

German Proposals for Constitutional and Community Approaches to IEL ...................................... 6

GERMAN AND EU 'ECONOMIC CONSTITUTIONALISM’ AS RESPONSES TO 'CONSTITUTIONAL

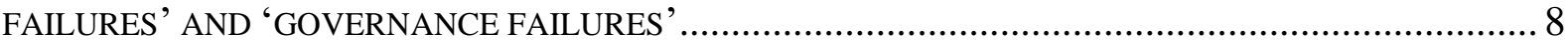

GERMAN ‘ORDO-LIBERALISM’ AIMED AT PROMOTING RULES-BASED, EUROPEAN AND

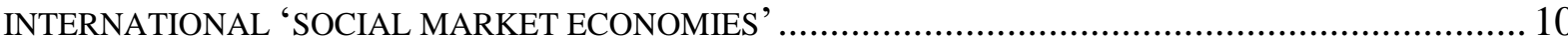

WHY MULTILEVEL GOVERNANCE OF THE GLOBAL ECONOMY REQUIRES MULTILEVEL

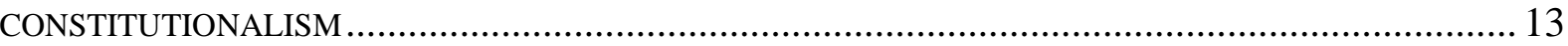

CONCLUSION: MULTILEVEL CONSTITUTIONALISM AS A 'GENTLE CIVILIZER' FOR A COMMON LAW

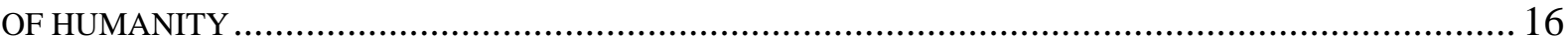

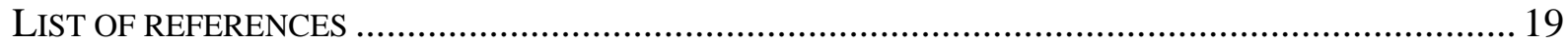





\section{Introduction*}

Similar to the Kantian insight that individuals construct their worldviews (e.g. dependent on time, space and human reasoning), also legal actors and democratic people identify, interpret and develop law and legal systems from their particular individual, social and cultural perspectives and democratic preferences. The internal perspectives of legal actors (e.g. citizens deriving and justifying their national Constitution from an agreed 'foundational norm' like human dignity as the 'Grundnorm' of the German Basic Law of 1949) and their external points of view (e.g. citizens and states claiming 'sovereign equality' and 'inalienable human rights' in their transnational relations) interact in diverse ways depending on their respective interests, histories, legal roles, 'public reason' or biases. Globalization increasingly transforms the reality of diverse national and international legal systems into transnational integration law based on mutual recognition of 'legal pluralism' and 'overlapping, functional regimes' for collective supply of transnational public goods (PGs). This contribution discusses the contribution of German-speaking countries to the evolution of European and international economic law (IEL) since World War II. This 'legal perspectivism' focusing on cooperation among German-speaking countries in and beyond European integration law - as a particular field of international law that has succeeded in limiting ('constitutionalizing') some of the failures of the pre-1945 international legal system - is justified not only by the genius loci of the conference leading to this book, i.e. the University of Innsbruck with its traditionally close cooperation with neighbouring universities in Germany, Italy and other 'core member states' of the European Union (EU), whose national approaches to international law are discussed in various chapters of this book. As emphasized in the book contributions on Austrian and German post-war approaches to international law, my focus on ordo-liberalism and constitutionalism as two defining characteristics of the post-1945 design and evolution of European and IEL - appears also justified and confirmed by the 'constitutional embeddedness' of foreign and international legal policies in post-war Austria and Germany, as demonstrated in the book chapter by Tomuschat and explained by Professor Köck's and Professor Verdross' 'Vienna School of international law' (e.g. emphasizing 'principles of justice' for justifying a coherent 'constitution of the international law community'). Without the 'constitutional post-war transformations' of Austria, Germany and other EU member states, the constitutional transformations of international law in Europe would hardly have been possible. The multilevel constitutional and judicial restraints on transnational economic integration continue to distinguish 'European international law' in unique ways from regional international law in Africa, the Americas and Asia where, due to different contexts and legal traditions, regional integration courts and human rights courts - and their 'multilevel judicial governance' protecting transnational ruleof-law and human and constitutional rights of citizens in cooperation with national courts - remain absent or much less developed. As argued in my contribution, ordo-liberalism (rather than Anglo-Saxon neo-liberal utilitarianism or authoritarian state-capitalism) and multilevel constitutionalism (rather than constitutional nationalism) can be seen as two defining characteristics of the post-1945 approaches of German-speaking countries to developing and reforming European and international law. Yet, legal perspectivism explaining particular 'European law approaches' acknowledges the universality of modern worldwide treaty systems based on respect for 'sovereign equality of states' and human rights law protecting individual and democratic diversity of peoples and individuals, including diversity of their national legal systems and policy perspectives.

\footnotetext{
* E.U.Petersmann is emeritus Professor of international and European law and former head of the Law Department of the European University Institute at Florence (Italy); ulrich.petersmann@eui.eu. This contribution will be published in P.Hilpold (ed), The European International Law Traditions, Springer Publisher 2020.
} 
IEL in Europe evolved in the Mediterranean area based on international trade agreements (e.g. among ancient city republics) and protection of freedom of commerce, related payments and private property (e.g. under Roman commercial and monetary law). With the emergence of ever more nation states, national conceptions of international law became ever more influenced by particular national interests (e.g. in colonial expansion), experiences and diverse traditions (e.g. among European civil law and common law countries). As illustrated by the common law freedoms invoked by English citizens and American settlers as constitutional constraints on abuses of 'sovereignty', or by the diverse codifications of human rights in national Constitutions and international treaties, international law was never a universal lingua franca based on commonly shared truths. Also inside German-speaking federal states like Austria, Germany and Switzerland, there is no 'neutral', common conception of international law or of IEL. Yet, their common experiences with the creation of common markets, federal states and 'constitutional failures' provoking World Wars I and II have prompted German-speaking countries to endorse - albeit in different ways - 'constitutional approaches' in post-war European economic regulation, either as members of the European Union (EU, e.g. Austria and Germany), the European Economic Area (EEA, e.g. Lichtenstein), or of the European Free Trade Area (EFTA, e.g. Switzerland). Following World War II, national parliaments, citizens and legal practitioners in German-speaking countries emphasized the need for democratic, judicial and other, constitutional restraints of foreign policy and economic policy powers so as to better protect citizens and their constitutional rights. As law exists primarily in the human mind and legal practices of citizens and of legal practitioners, it is important to understand the particular perspectives, rules-based theories and conceptions of IEL influencing the legal practices of governmental and non-governmental actors from German-speaking countries. For instance, the post-war adoption by all 31 EEA member countries of national competition laws administered by independent competition authorities, of independent national central banks protecting monetary stability, and of European common market rules was influenced by ordo-liberal leadership from German-speaking countries conceiving markets as 'legal constructs' (e.g. requiring constitutional protection of fundamental rights, legal and institutional limitations of 'market failures' and 'governance failures') rather than as 'natural orders'. ${ }^{1}$ Similarly, the 'proportionality balancing' in the case-law of the German Constitutional Court, its judicial dialogues with the European Court of Justice (CJEU), and its related 'solange jurisprudence' influenced also the cooperation among national courts in other European countries with the CJEU, the EFTA Court and the European Court of Human Rights (ECtHR). The Maastricht and Lisbon Treaties' commitment to a 'competitive social market economy' (Article 3 TEU) was influenced by German traditions of a 'social market economy' embedded into Germany's constitutional commitment to social justice ('Sozialstaat'). The legal design and commitments of the European Monetary Union (EMU) to monetary and price stability, central bank independence, fiscal and debt disciplines and 'no bail-out' clauses were, likewise, influenced by the post-war legal traditions of German-speaking countries. Yet, there remain important constitutional differences among German-speaking countries (as illustrated by Switzerland's 'neutrality' and 'referendum democracy', Liechtenstein's monarchy), which explain important differences in their external economic policies (e.g. the rejection by Swiss voters of membership in the EU and EEA).

German and European 'ordo-liberalism' emphasize the 'interdependence of orders' and of social subsystems (like civil societies, the economy, the polity, legal and cultural systems), as it has become recognized also in modern constitutional law (e.g. the EU Charter of Fundamental Rights, EUCFR) and in human rights law based on 'inalienable' and 'indivisible' civil, political, economic, social and cultural rights. This contribution focuses on 'constitutional', 'ordo-liberal' and 'social market economy approaches' advocated by German-speaking countries for regulating post-war IEL so as to avoid a repetition of historical experiences (e.g. during the 1920s and 1930s) with 'market failures', 'governance

\footnotetext{
${ }^{1}$ On the ordo-liberal Freiburg School of law and economics as a predecessor of 'constitutional economics', and on the contrast between neo-liberal 'free market economics' and ordo-liberal 'constitutional economics', see: V.J.Vanberg, The Constitution of Markets. Essays in Political Economy (London: Routledge, 2001).
} 
failures' and 'constitutional failures'. Section 2 recalls five competing conceptions of IEL, which tend to interpret, analyze and develop IEL rules and institutions from diverse perspectives and value premises. Section 3 uses the example of German and European constitutional law as an illustration of how the 1919 Weimar Constitution, the 1949 Basic Law of Germany, EU and EEA law developed complementary conceptions of 'constitutionalism' for multilevel regulation of PGs like the national and international economy:

1. as national and functionally limited transnational legal constitutions constituting, limiting, regulating and justifying the basic legal order of a people based on agreed 'principles of justice' of a higher legal rank, including 'constitutional methodologies' for designing and interpreting the 'rules of recognition, change and adjudication' as 'principal-agent' relationships between citizens and governance agents with limited, delegated powers;

2. as ideal constitutions mandating progressive 'constitutionalization' of law and governance through transformation of the agreed 'constitutional principles' into constitutional law, democratic legislation, administration, adjudication, international agreements and institutions; and

3. as real constitutions based on social and legal practices and local cultures ('law in action') that may differ from the legal and ideal constitutional projects and 'law in the books'.

Section 4 recalls how German conceptions of 'ordo-liberalism' and 'social market economy' were developed since the 1930s and continue to influence the design of European and IEL, for instance the EMU as an instrument for protecting monetary stability and for 'consolidating' the budget- and debtdeficits of over-indebted EMU member states. Section 5 discusses German proposals for applying 'constitutional economics' for the legal design of multilevel governance of the global economy; the facts of economic and legal globalization, the universal recognition of human rights, and the transformation of national into transnational PGs require supplementing intergovernmental UN/WTO governance by citizen-driven 'cosmopolitan network governance' (e.g. of human rights, health, environmental and privacy protection of citizens) that empowers citizens to hold multilevel governance institutions legally, democratically and judicially more accountable. Section 6 concludes that - in European economic integration law and WTO law - multilevel legal and judicial protection of transnational economic freedoms and rule-of-law has served as a 'gentle civilizer' for a common law of humanity as predicted by Kantian legal theory. Yet, the United Kingdom's 'Brexit' from the EU on 31 January 2020 and the invocation by the United States' (US) Trump administration - since 2018 - of national security exceptions for undermining the WTO legal and dispute settlement system (e.g. by 'trade wars' against China, illegal steel and aluminium tariffs, 'blocking' of the WTO Appellate Body) seems to introduce a new era of IEL with increasing conflicts between European 'economic ordo-liberalism' as supported by German-speaking countries, hegemonic US neo-liberalism and China's totalitarian state-capitalism.

\section{Competing conceptions of international economic law}

International movements of goods, services, persons, capital and related payments have existed since ancient times (e.g. between the Mediterranean, India and China). Yet, up to the 1800s, production of goods and services remained essentially local. In spite of some international trade and investment agreements, IEL was essentially part of domestic legal systems (e.g. the Roman jus gentium regulating commerce with foreigners under the administration of the praetor peregrinus). The industrial revolution (e.g. use of steam power in factories, railways and navigation) and colonialism promoted globalization and the North-South income divide known as the 'great divergence' in the international division of labor. The 1990s ushered in today's 'great convergence' in the global division of labor based on information technologies enabling transnational corporations (TNCs) to move labor-intensive work and know-how (e.g. for production, management and marketing) abroad to less developed countries (LDCs) propelling 
their rapid industrialization through 'global production' and trade of goods, services and technologies. ${ }^{2}$ German-speaking countries - notwithstanding their little involvement in colonization - actively participate in this 'new globalization', which continues to change the world economy and its legal regulation. The more nations and firms engage in 'international production' based on 'global supply chains' that enable shifting industries to lower-cost countries like the BRICS (i.e. Brazil, Russia, India, China and South Africa), the more conceptions of IEL went beyond the traditional conceptions of IEL as (1) public international law among states (e.g. the 1944 Bretton Woods Agreements, GATT 1947) ${ }^{3}$ and (2) private international commercial law and 'conflicts law'. ${ }^{4}$ The emergence of hundreds of worldwide and regional organizations for the collective supply of transnational PGs promoted the legal conceptualization of (3) IEL and the law of international organizations as 'global administrative law' (GAL). ${ }^{5}$ In view of the legal primacy and 'direct effects' of European common market law vis-à-vis domestic legal systems, EU law and - in less supra-national ways - also EEA law were construed by European and national courts as (4) multilevel constitutional law protecting also human rights and fundamental rights of citizens. The more the regulation of international monetary, financial, trade and investment organizations became influenced by economic theories (e.g. on the 'separation of policy instruments' and their 'optimal, efficient ranking', e.g. in GATT/WTO law), the more legal doctrines also recognized the need for (5) understanding IEL, and protecting its coherence, in terms of multilevel economic regulation (e.g. of tariffs and non-tariff border barriers, domestic regulations 'behind borders' like competition rules, subsidies and taxes). ${ }^{6}$

\section{From Constitutionalism 1.0 to Constitutionalism 3.0 in European Integration}

From the Westphalian peace treaties (1648) up to World War II, the 'international law of coexistence among sovereign states' was developed on the basis of power-oriented concepts like state sovereignty and legal positivism (e.g. distinguishing treaties, customary law and general principles of 'hard law' from legally non-binding 'soft law', justifying colonialism and wars). Due to the universal recognition of 'inalienable' and 'indivisible' human rights following World War II, the UN 'international law of cooperation', regional and national human rights law increasingly limit state-centred interpretations of the 'sources of international law' by legal and judicial protection of civil, political, economic, social and cultural rights of citizens, peoples and economic actors, including rights and remedies of producers, investors, traders and consumers in trade, investment, regional economic and human rights agreements. 'Constitutionalism 1.0' (like the democratic American and French Constitutions during the eighteenth century, the Austrian, German and Swiss Constitutions during the 19th century) had focused on emancipation of peoples in nation states, the constitution of government powers, and the creation of common markets. A second wave of 'human rights constitutionalism 2.0' after World War II was based

${ }^{2}$ Cf. R.Baldwin, The Great Convergence. Information Technology and the New Globalization (Cambridge Mass: Harvard UP 2016).

${ }^{3}$ For this state-centered conception of IEL see, e.g., G.Schwarzenberger, The Principles and Standards of International Economic Law, 117 Recueil des Cours (The Hague: Nijhoff 1966), 1-98; I.Seidl-Hohenveldern, International Economic Law, 198 Receuil des Cours (The Hague: Nijhoff 1986), 3-264.

4 An example for a private law-centered conception of IEL is: B.Schöbener/J. Herbst/M. Perkams, Internationales Wirtschaftsrecht (Heidelberg: Müller 2010). Also the Internationales Wirtschaftsrecht edited by C.Tietje (Berlin: De Gruyter, 2009) and M.Herdegen's Principles of International Economic Law (Oxford: OUP 2013) include chapters on 'international business law' and transnational private law.

${ }^{5}$ See, e.g. R. Stewart and R.M. Ratton Sanchez Badin, 'The WTO and Global Administrative Law' in: C. Joerges/E.U. Petersmann (eds), Constitutionalism, Multilevel Trade Governance and International Economic Law (Oxford: Hart 2011), chapter 16 .

${ }^{6}$ For detailed explanations of these five competing conceptions of IEL see: E.U.Petersmann, International Economic Law in the 21 st Century. Constitutional Pluralism and Multilevel Governance of Transnational Public Goods (Oxford: Hart 2012), ch. 1 . 
on national, regional and worldwide commitments (e.g. in UN law) to protection of civil, political, economic, social and cultural human rights and popular self-determination, including legal requirements of interpreting treaties 'in conformity with the principles of justice' such as 'human rights and fundamental freedoms for all' (as recalled in the Preamble and Article 31 of the 1969 Vienna Convention on the Law of Treaties, VCLT). European integration prompted adjustments of many national Constitutions and the emergence of functionally limited, multilevel constitutional law among the (until 2020) 28 EU member states as well as among third states participating in the EEA, as illustrated by the interpretation of EU and EEA law by national courts, the CJEU and the EFTA Court as multilevel constitutional legal systems protecting constitutional and human rights of citizens. This multilevel European 'cosmopolitan constitutionalism 3.0 ${ }^{\prime 7}$ aims at protecting and emancipating citizens vis-à-vis abuses of national foreign policy powers through multi-level treaty law and institutions constituting, limiting, regulating, and justifying multi-level governance of transnational PGs (like common markets, transnational rule of law, multi-level legal and judicial protection of cosmopolitan rights). The farreaching repercussions of this multilevel constitutionalism on IEL are illustrated by European constitutional and common market law, EU membership in worldwide organizations like the World Trade Organization (WTO) and Food and Agriculture Organization (FAO), and by the ever-larger number of international courts protecting rights not only of states, but also of individuals.

\section{Homo Economicus: Competing Actors Prioritize Competing Self-Interests}

The competing conceptions of IEL ('legal perspectivism') are often due to competing value premises prioritized by different economic actors. For instance: Governments tend to insist on 'state sovereignty', 'national interests', intergovernmental conceptions of 'IEL as public international law among states regulating the international economy' (e.g. the 1944 Bretton Woods Agreements, GATT 1947), and on intergovernmental management of IEL so as to protect the regulatory discretion of governments and limit their legal, democratic and judicial accountability vis-à-vis citizens. Private economic actors interested in using and protecting their private legal and economic autonomy in the global division of labor perceive IEL primarily as private international transaction law, commercial and corporate law, 'conflicts law', labor law and consumer protection law. Citizens, democratic institutions, and courts of justice in constitutional democracies increasingly perceive IEL from democratic and republican perspectives so as to insist on multilevel, democratic regulation of PGs and of related 'market failures' and 'governance failures' (e.g. through national competition, consumer protection, trade, environmental, labor law and social legislation as preconditions for the proper functioning of a 'social market economy'). EU citizens, their EU Member States, and representative EU institutions view European economic law as being embedded into multi-level constitutional regulation of their common market and of multi-level governance of other European PGs (like transnational rule of law, multi-level protection of human and constitutional rights of EU citizens), even if third European countries insist on maintaining their diverse constitutional traditions in designing IEL, like the EFTA countries participating in the European common market on the basis of the EEA Agreement of 1993. Worldwide organizations - like the UN Specialized Agencies and the WTO - and ever more regional economic organizations recognize that their primary and 'secondary' treaty law is increasingly limited by 'GAL' principles protecting transparency, legal and judicial accountability, and rule of law in multi-level governance of transnational PGs (like monetary stability, the world trading system, world food security, public health protection). Academic analyses of IEL often disagree on how these five competing conceptions of IEL as (1) international law based on state sovereignty; (2) private international law based on private autonomy rights; (3) multi-level economic regulation based on 'law and economics'; (4) multi-level constitutional law deriving its legitimacy from protecting human rights (like individual and democratic self-

\footnotetext{
${ }^{7}$ Cf. E.U.Petersmann, Multilevel Constitutionalism for Multilevel Governance of Public Goods - Methodology Problems in International Law (Oxford: Bloomsbury 2017); A.Somek, The Cosmopolitan Constitution (Oxford: OUP 2014).
} 
determination); or (5) as GAL based on respect for the reality of 'constitutional pluralism' should be evaluated and reconciled with each other.

\section{German Proposals for Constitutional and Community Approaches to IEL}

World Wars I and II had made evident to German-speaking lawyers how much the domination of 'international law among states' by intergovernmental power politics - notably the dis-connect of international law from effective constitutional restraints protecting human rights, rule of law and constitutional democracy (e.g. as prescribed in Germany's Weimar Constitution of 1919) - risked undermining the democratic capacity of peoples to protect transnational PGs. The legal formalism justifying the transfer of totalitarian powers to the Nazi dictatorship and its racial discrimination ushering in the holocaust prompted many German post-war lawyers to challenge 'legal formalism', including formalistic distinctions between lege lata and lege ferenda in view of the policy functions of constitutional and human rights for protecting corresponding PGs like a 'social market economy', constitutional democracy and international 'democratic peace'. The universal recognition by UN member states of human rights, rule of law and democratic governance as - albeit indeterminate and often not effectively implemented - 'general principles of UN law'8 justified 'constitutional conceptions' of the customary law requirements of interpreting treaties not only in good faith based on the text, context, object and purpose of treaty provisions, but also with due regard to 'any relevant rules of international law applicable in the relations between the parties' and 'in conformity with the principles of international law', including, inter alia, 'the principles of the equal rights and self-determination of peoples' and 'observance of human rights and fundamental freedoms for all' (as codified in the Preamble and Article 31 of the VCLT). The history of governmental justifications of war on religious, feudal or nationalist grounds confirmed this need for limiting 'state sovereignty' and foreign policy discretion by 'higher constitutional restraints', as reflected also in UN law (e.g. Article 103 UN Charter) and in the jus cogens core and erga omnes nature of multilevel human rights law. Austrian, German and Swiss international lawyers became leading advocates of interpreting European law, UN law and international courts of justice as 'constitutional instruments' for protecting the 'international community', fundamental rights of citizens and erga omnes human rights obligations. ${ }^{9}$ If national and international legal systems are based on similar legal principles (like equal freedoms, non-discrimination, rule of law and judicial remedies), respect for the human and constitutional rights of citizens may require interpreting multilevel economic regulation in mutually coherent ways protecting rights of governments in conformity with the civil, political, economic, social and cultural rights of their citizens. ${ }^{10}$

Political disagreements on legal and economic principles in IEL often reflect power struggles. How should state-centred 'principles of justice' (like sovereign equality of states), peoples-centred principles

${ }^{8}$ Cf F.Ehm, Das völkerrechtliche Demokratiegebot. Eine Untersuchung zur schwindenden Wertneutralität des Völkerrechts gegenüber den staatlichen Binnenstrukturen (Tübingen: Mohr 2013).

${ }^{9}$ Cf A.Verdross, Die Verfassung der Völkerrechtsgemeinschaft (Springer 1926); H.Lauterpacht, The Function of Law in the International Community (Clarendon Press 1933); H.Mosler, The International Society as a Legal Community 140 Recueil des Cours (1974) 1; B.Simma, From Bilateralism to Community Interest in International Law 250 Recueil des Cours (1994) 217; B.Fassbender, The UN Charter as Constitution of the International Community (The Hague: M.Nijhoff 2009); A.von Bogdandy, Constitutionalism in International Law: A Proposal from Germany, in: 47 Harvard International Law Journal (2006) 223

${ }^{10}$ Cf. E.U.Petersmann, Constitutional Functions and Constitutional Problems in International Economic Law (Fribourg University/Boulder Press 1991, re-print 2020); idem, State Sovereignty, Popular Sovereignty and Individual Sovereignty: From Constitutional Nationalism to Multilevel Constitutionalism in International Economic Law? in: W.Shan/P.Simons/D.Singh (eds), Redefining Sovereignty in International Economic Law (Oxford: OUP 2008), 27-60; T. Cottier/M.Hertig, The Prospects of 21st Century Constitutionalism' in: A. von Bogdandy/R.Wolfrum (eds), Max Planck Yearbook of United Nations Law 7 (Brill/Nijhoff 2004) 261-328; M.Herdegen, Principles of International Economic Law (Oxford: OUP 2nd ed. 2016). 
(like democratic self-determination of peoples), human rights and fundamental freedoms for all be reconciled with each other in multi-level economic regulation? Constitutionalism aims at limiting and structuring post-constitutional politics; but the constitutional mandate for legislative, administrative, judicial and international protection of PGs also includes a legal framework prescribing vast policy programs for future 'PGs politics' The more globalization diminishes the capacity of states to protect PGs without international law and multilevel governance institutions, the stronger becomes the need for 'constitutionalizing' multilevel governance of transnational PGs, ${ }^{11}$ for instance by limiting abuses of regulatory powers through 'GAL constraints' (like transparency, legality, consultation, participation, justification, proportionality, judicial remedies, subsidiarity). As human rights recognize citizens as 'constituent powers' and 'democratic principals' of multilevel governance institutions with limited, delegated powers, German 'international community advocates' argue that the constitutional rights of citizens and peoples limit the rights of states under both national and international legal systems. ${ }^{12}$ Some German-speaking economic lawyers emphasize that procedural, distributive, corrective, commutative justice and equity continue to be recognized as diverse 'spheres of justice' also in the design and justification of IEL and related legal and dispute settlement systems (e.g. for 'violation complaints', 'non-violation complaints', and 'situation complaints' pursuant to Art XXIII GATT). Post-colonial IEL also includes 'principles of transitional justice' based on preferential treatment of LDCs (e.g. in Part IV of GATT and in the dispute settlement system of the WTO), as well as 'cosmopolitan principles of justice' based on the universal human rights obligations of all UN Member States. Such different 'principles of justice' reflect human struggles for emancipation and liberation from abuses of public and private powers. ${ }^{13}$ The failure of WTO Members to conclude their 'Doha Development Round' negotiations, and the more than 600 WTO disputes since 1995 illustrate disagreements among governments and non-governmental actors on how 'principles of justice' should guide and limit trade regulation and adjudication inside and outside the WTO. EU citizens have succeeded in 'constitutionalizing' their national and European legal systems by linking fundamental rights of citizens to multi-level governance duties to protect PGs. Yet, similar 'constitutional approaches' (e.g. deriving the legitimacy also of international trade and investment law from 'constitutional contracts' among citizens and from respect for their 'inalienable' constitutional rights) are resisted by UN and WTO diplomats, for instance if they defend authoritarian, foreign policy discretion by the need for 'realism' in intergovernmental power politics and resist their legal and judicial accountability in domestic courts for governmental violations of treaties approved by parliaments for the benefit of citizens. Similar to the diverse political theories on governance inside states and on designing 'private-public partnerships' (e.g. for supplying PGs such as financial stability and public health), views on multi-level trade and economic regulation differ depending on the diverse conceptions of foreign policies and international relations. The new challenges of the traditional separation of the world trading and security systems by US invocations of national and international security exceptions for disrupting multilateral (e.g. WTO) treaty systems reflect not only populist denials by government executives of international jurisdictions (e.g. by the US of the WTO dispute settlement system, by the UK of the CJEU), but also of national constitutional and democratic (e.g. parliamentary) constraints so as to exploit executive powers.

\footnotetext{
${ }^{11}$ Cf. Petersmann (notes 7 and 10) and A.Peters, Compensatory Constitutionalism : The Function and Potential of Fundamental International Norms and Structures, in : 19 Leiden Journal of International Law (2006) 579.

${ }^{12}$ On the foundational role of human rights for designing 'constitutionalism' see : E.J.Schwöbel, Global Constitutionalism in International Legal Perspective (Brill 2011); E.U.Petersmann, 'Constitutional Constructivism' for a Common Law of Humanity? Multilevel Constitutionalism as a 'Gentle Civilizer of Nations' in: Max Planck Institute MPIL Research Paper Series No. 2017-24.

13 Cf Petersmann (note 7); R.Forst, Contexts of Justice : Political Philosophy beyond Liberalism and Communitarianism (University of California Press 2002).
} 


\section{German and EU 'economic constitutionalism' as responses to 'constitutional failures' and 'governance failures'}

The German Basic Law of 1949 had been designed so as to exclude a repetition of the 'constitutional failures' of the 1919 Weimar Republic, such as 'emergency regulations' violating fundamental rights, distorting the economy (e.g. through governmental price, interest and wage regulations), and ushering in dictatorship, war and genocide. ${ }^{14}$ Even though Germany's post-war market economy was embedded into comprehensive constitutional guarantees (e.g. of fundamental rights, judicial remedies, monetary stability, social justice principles like the 'Sozialstaat'), the German Constitutional Court emphasized the 'relative economic openness' of the Grundgesetz; it rejected academic proposals to interpret the Basic Law as guaranteeing a 'social market economy'. ${ }^{15}$ The German negotiators of the EEC Treaty (like W.Hallstein, Müller-Armack) insisted on embedding the common market into the liberal customs union rules of the General Agreement on Tariffs and Trade (GATT 1947), strong competition rules, 'social market economy' rules and constitutional restraints aimed at institutionalizing 'ordo-liberal public reason' (e.g. through independent, national and European competition authorities and courts of justice) and preventing a return to laissez-faire liberalism, socialist planning, and 'democratic failures'. The EU's micro-economic common market constitution protecting 'market freedoms', fundamental rights and a 'highly competitive social market economy' remains strongly influenced by German traditions of 'ordo-liberalism', i.e. the conception of markets as legal constructs whose proper functioning requires systemic limitations of 'market failures' (e.g. through competition, environmental and social legislation) as well as of 'governance failures' (e.g. though constitutional protection of civil, political, economic and social rights and judicial remedies). German politicians expected the Maastricht Treaty's Economic and Monetary Union - with its macro-economic monetary constitution prescribing budgetary, price and monetary stability - to complete the ordo-liberal project of limiting regulatory discretion - and related interest group politics and 'rent-seeking' - through constitutional and legislative rules, independent institutions (like national and European central banks) and multilevel legal and judicial protection of fundamental rights. In view of the 'subsidiarity principles' in German-speaking federal states, Austria and Germany are critical of alternative 'fiscal federalism proposals' for more comprehensive EU resources to address structural inequalities and prevent 'asymmetric shocks' (e.g. by EU stabilization and financial assistance tools). The 2009 Lisbon Treaty continued this 'surveillance paradigm' respecting the fiscal and economic policy powers of EU member states and strengthening the role of EMU and Euro institutions as 'discipline enforcers' supervising national economic and fiscal policies. ${ }^{16}$ This incomplete and inflexible 'constitutional approach' prioritizing coordination (e.g. rather than harmonization of fiscal, economic, social and unemployment policies) underestimated, however, that - similar to the financial, economic, monetary and constitutional crises during the Weimar Republic - the financial, sovereign debt, economic and social crises, since 2008, prompted increasing rule violations in many EU member states due to their diverse political traditions (e.g. in defending rule of law against rent-seeking interest group pressures from uncompetitive producers, failing banks and socially disadvantaged citizens).

Do the frequent departures from rule of law inside the EU (e.g. non-compliance with the budget and debt disciplines in Article 126 TFEU) impede effective 'constitutionalization' of economic, financial and monetary politics inside and beyond the EU? Just as theories of justice (e.g. justifying rules on the

\footnotetext{
${ }^{14}$ The failures of liberalism, democracy and of economic planning during the inter-war period, and the resulting financial, economic and democratic crises impeding the enforceability of the social rights guarantees in the Weimar Constitution, were described in F.A.Hayek, The Road to Serfdom (Routledge 1944). See also E.Kennedy, Constitutional Failures. Carl Schmitt in Weimar (Durham: Duke University Press 2004).

${ }^{15}$ For an overview of academic views and the jurisprudence of the Constitutional Court see: J.Drexl, Competition Law as Part of the European Constitution, and A.Hatje, The Economic Constitution, in: A von Bogdandy/J.Bast (eds), Principles of European Constitutional Law (Oxford: Hart 2006), 587ff, 633ff.

${ }^{16}$ Cf. A.Hinarejos, The Euro-Area Crisis in Constitutional Perspective (OUP 2015); M.Adams/ F.Fabbrini/P.Larouche (eds), The Constitutionalization of European Budgetary Constraints (Hart 2014).
} 
basis of Kantian 'moral imperatives' and 'constitutional conventions' among free and reasonable citizens) had not prevented 'unpolitical Germans' to support 'constitutional failures' undermining the Weimar Constitution (e.g. 'Weimar liberalism' being undermined by executive 'emergency politics', as justified by Hitler's legal advocate Carl Schmitt), so is the European 'ordo-liberal constitution' progressively transformed by financial, economic, social, migration, security and rule-of-law crises, the emergence of 'illiberal politics' (e.g. in Hungary, Poland) and opportunistic 'populism' (e.g. in the UK's 'Brexit referendum'). The 'new nationalism' (e.g. in the UK and the USA) and increasing number of authoritarian rulers and extremist political parties illustrate the lack of homogeneity of 'political cultures' in EU member states ushering in political conflicts caused by 'unreasonable and irrational, and even mad, comprehensive doctrines' that risk undermining law and justice in societies unless 'public reason' is effectively institutionalized. ${ }^{17}$

The global financial crisis of 2008 entailed increasing disregard by EU Member States for the budget and debt disciplines of Article 126 TFEU. The 'bail out'- and related 'credit facility'-prohibitions in Articles 123-125 TFEU, which reflected Germany's insistence on constitutional commitments to fiscal and monetary stability, did not prevent the EU and its Member States to respond positively to requests for - by 2017 - ten 'sovereign debt programs' disbursing around 500 billion euros since 2008 in favor of euro area states (Greece, Ireland, Portugal, Cyprus), as well as balance of payments loan assistance under Article 143 TFEU for other EU Member States (Hungary, Latvia, Romania). ${ }^{18}$ The fact that also Greece exited its sovereign debt program illustrates not only the success of most of these programs; it also seems to confirm the 'deeper underlying problem' that - in weak political systems where politicians fail to defend the rule of law (e.g. the budget and debt disciplines of Article 126 TFEU) - 'the public debt is high because the government is willing to pay for the losses of small, well-organized groups' rather than to defend 'the collective interests of taxpayers' ${ }^{19}$ The numerous legal and judicial challenges of EU, intergovernmental and national 'emergency measures', of their 'austerity conditions' (e.g. imposing cuts of wages, pensions, social security assistance and bank depositor rights in over-indebted countries) and alleged, related human rights violations reveal that - notwithstanding important legal clarifications by the CJEU (notably in the Pringle, Gauweiler and Ledra cases) on the scope of the monetary policy powers of the EU and of the ECB - civil society, parliaments and governments in the EU disagree on the legal limits and future design of the EMU (e.g. debt relief measures as requested by the International Monetary Fund, scope of 'austerity restrictions' imposed by loan agreements on fundamental rights, creation of a 'new European Social Pillar' proposed by EU Commission President Juncker, transformation of the EMU into a 'transfer Community' as requested by some over-indebted Mediterranean countries as compensation for their weak legal and political systems). ${ }^{20}$ The more 'governance failures' (e.g. in the EMU and related banking supervision) led to redistribution of taxpayers' money (e.g. more than 4,5 trillion euros used to rescue banks in the EU by 2012), the more citizens question the legitimacy of redistributive policies aimed at compensating 'market failures' and 'regulatory failures' through inter-governmental agreements and EU institutions (e.g. the ECB's use of monetary powers to purchase unlimited amounts of securities reducing the interest rates on private bank investments and turning the ECB effectively into a lender of last resort). The continued use of public

${ }^{17}$ Cf J.Rawls, Political Liberalism (Columbia University Press 1993) xvi-xvii.

18 This does not not include the very substantial financial sector assistance granted to Spain under the European Stability Mechanism (ESM) and the European Central Bank (ECB)'s indirect financial assistance measures.

${ }^{19}$ D.Gros, The Italian Banking Saga : Symptom of a deeper underlying problem? In : CEPS Thinking ahead for Europe, 7 July 2017 (http://www.ceps.eu/publications).

${ }^{20}$ For analyses of the relevant case-law see: T.Beukers/B. De Witte/C. Kilpatrick (eds) Constitutional Change Through EuroCrisis Law (CUP 2017). In Pringle, the CJEU construed the bail-out prohibition in Article 125 TFEU as 'not intended to prohibit either the Union or the Member States from granting any form of financial assistance whatever to another Member State' (Case C-370/12, EU:C:2012:756, para.130). In the Dano judgment of 11 November 2014, the CJEU allowed EU member states to exclude economically inactive EU citizens from certain national social benefits if freedom of movement was used only in order to obtain another member state's social assistance (C-333/13, EU:C:2014:2358), thereby allaying fears of 'welfare tourism'. 
tax income for bailing-out private banks (e.g. in Italy 2017), the suspension of the 'Dublin'- and 'Schengen-rules' in response to uncontrolled migration flows, repeated terrorist attacks and security threats inside EU member states, and the 'Brexit referendum' of June 2016 transformed the economic crises into a broader identity crisis of EU citizens, including both citizens using their rights under the EUCFR to move abroad and those staying in their state of origin (e.g. claiming rights of access to EU documents, rights of communication with EU institutions, launching 'citizen initiatives' pursuant to Article $11 \mathrm{TEU}){ }^{21}$ The widespread civil society protests against the Canada-EU Comprehensive Economic and Trade Agreement (CETA), the EU-USA Transatlantic Trade and Investment Partnership (TTIP) negotiations, and against other, non-inclusive EU policies (e.g. vis-à-vis illegal migrants) reveal increasing distrust of EU citizens vis-à-vis alleged abuses of EU powers and intergovernmental responses (e.g. creating the ESM as an intergovernmental organization with a budget of 700 billion euros for bailing-out indebted member states and troubled banks).

\section{German 'ordo-liberalism' aimed at promoting rules-based, European and international 'social market economies'}

Following World War II, the ordo-liberalism advocated by the 'law and economics' school at Freiburg University (founded by the lawyer G.Böhm and the economist W.Eucken in the 1930s) was complemented by 'social market economy' advocates (like Müller-Armack at Cologne University) and German politicians like chancellors Adenauer and Erhard. Both schools agreed on the need for regulating economic liberalism so as to promote social security and social acceptance of market competition (e.g. by protecting unemployment and pension insurances, universal health care and labor rights, active housing, education and employment policies) - without resorting to socialist ideas of economic planning and replacing private property by state capitalism. ${ }^{22}$ Yet, only the 'social market economy' advocates elaborated coherent political programs that - by embedding social policies into Germany's fundamental rights guarantees (e.g. protecting 'human dignity', labor and trade union rights) and the Basic Law's commitment to a 'social state' (Article 20), and justifying 'economic humanism' (W.Röpke) and 'social justice' by Christian traditions of promoting 'subsidiarity' and solidarity - were persistently endorsed by political majorities in democratic German elections. ${ }^{23}$ The Constitutional Court did not support legal claims that the comprehensive guarantees of the German Basic Law of economic freedoms, private property rights, labor and social rights constitutionally limited the economic policy discretion of the legislature by prescribing such a 'social market economy'. German politicians succeeded in persuading other EU member states to incorporate the political paradigm of a 'competitive social market economy' into EU law (e.g. Article 3 of the Lisbon Treaty), supplemented by constitutional guarantees of 'dignity rights' and other social rights (e.g. in the 2009 EUCFR, the 1989 Community Charter of Fundamental Social Rights of Workers), 'solidarity obligations' and 'subsidiarity principles' (e.g. in Article 5 TEU). These multilevel constitutional restraints continue to guide political resistance by German-speaking countries against redistributive claims (e.g. by Mediterranean countries

${ }^{21}$ Cf. V.Hatzopoulos, From Economic Crisis to Identity Crisis: The Spoliation of EU and National Citizenships, College of Europe Research Paper in Law 01/2017.

${ }^{22}$ On differences among these two schools see : J.Lange/von Kulessa/A.Renner, Die Soziale Marktwirtschaft Alfred Müller Armacks und der Ordoliberalismus der Freiburger Schule - Zur Unvereinbarkeit zweier Staatsauffassungen, in : ORDO 49 (Stuttgart 1998), 79-104. See also P.Commun, Erhards Bekehrung zum Ordoliberalismus, Freiburg Discussion Papers on Constitutional Economics 04/4 (Freiburg i.B. 2004). For Hayek's criticism of governmental 'social justice policies' as an alternative to income distribution based on market principles see: F.A.Hayek, The Fatal Conceit. The Errors of Socialism (University of Chicago Press 1991).

${ }^{23}$ Cf A.Müller-Armack, Wirtschaftsordnung und Wirtschaftspolitik. Studien und Konzepte zur Sozialen Marktwirtschaft und Europäischen Integration (Freiburg i.B. 1966). 
disregarding the budget and debt disciplines of Articles 123-126 TEU) for transforming the EU's rulesbased monetary and economic union into a 'social transfer union'. ${ }^{24}$

Due to their constitutional commitments to protection of economic and social rights and open market economies, German-speaking countries support membership in the Bretton Woods institutions, GATT, the WTO, regional free trade areas and investment agreements. They are also leading supporters of the EU's 'cosmopolitan foreign policy constitution' committing the EU's external policies to 'strict observance of international law', protection of human rights and coherence of internal and external EU policies (cf. Articles 3, 21 TEU and the EUCFR). ${ }^{25}$ Similarly, Austria, Germany and Switzerland tend to support 'human rights approaches' to international economic regulation, the 2030 Sustainable Development Agenda adopted by UN institutions, the 'exportation' of rule-of-law principles and judicial remedies through international agreements on the protection of foreign investments, and peaceful settlement of international disputes through international courts of justice and arbitration (e.g. under WTO law, the UN Convention on the Law of the Sea, the European Court of Human Rights, investorstate arbitration). In 1959, Germany was the first country to conclude a bilateral investment protection agreement with Pakistan. Since then, Austria, Germany and Switzerland remain leading supporters of the transformation of international investment law from a 'Westphalian' into a more 'cosmopolitan system', as it evolved since the 1960s in essentially five phases:

- Following the first bilateral investment treaty (BIT) between Germany and Pakistan in 1959, the number of BITs has dynamically increased to now more than 3.200 agreements. Yet, the 'first generation BITs' did not yet provide for direct access of the foreign investor to independent international arbitration.

- The 1965 World Bank Convention establishing the International Centre for the Settlement of Investment Disputes (ICSID), which entered into force already in 1966 (following 20 ratifications), offered a multilateral legal framework for institutionalized, transnational arbitration of investment disputes based on consent between the states and investors involved. The first ICSID disputes were based on investor-state contracts ${ }^{26}$ or on national legislation that provided for direct access of foreign investors to international arbitration. ${ }^{27}$

- Treaty-based investor-state arbitration was provided for only in the 'second generation BITs' concluded since 1969. In view of its many advantages for private investors (e.g. in terms of direct access to independent international arbitration usually without prior exhaustion of local remedies, direct control of the procedures without dependence on 'diplomatic protection', availability of institutionalized ICSID procedures), most modern BITs provide for treaty-based investor-state arbitration. $^{28}$

- In contrast to the less than 400 BITs concluded prior to 1989, the number of new BITs increased dramatically since the 1990s and exceeds now 3.200 BITs and corresponding treaty provisions in free trade agreements (like NAFTA Chapter XI) and other sectorial agreements (like the Energy Charter Treaty which entered into force in 1998). The number of BITs and related investor-state dispute settlement (ISDS) among LDCs also continues to increase.

\footnotetext{
${ }^{24}$ As a much higher percentage of the average families in France, Italy or Spain live in their privately owned homes than in Austria and Germany (e.g. due also to destruction of cities during World Wars I and II and the post-war influx of millions of German-speaking refugees from Eastern Europe), and Germany continues to pay the largest national contribution to EU budgets, German resistance against calls for new EU 'social programs' (like an EU unemployment guarantee, transformation of national debts into EU debts) is likely to continue on grounds of 'subsidiarity' and rule of law (e.g. defending the EU budget and debt disciplines against rent-seeking pressures).

${ }^{25}$ Cf. E.U.Petersmann, The EU's Cosmopolitan Foreign Policy Constitution and its Disregard in Transatlantic Free Trade Agreements, in: European Foreign Affairs Review 2016, 449-469.

${ }^{26}$ The first ICSID dispute based on an investor-state contract was Holliday Inns v Morocco, ICSID Case No. ARB/72/1.

${ }^{27}$ The first ICSID dispute based on national legislation was SPP v Egypt, ICSID Case No. ARB/84/3.

${ }^{28}$ The first ICSID dispute based on a BIT clause was AAPL v Sri Lanka, ICSID Report IV, at 250.
} 
- Since the 1990s, the number of treaty-based ICSID disputes, or investor-state disputes based on UNCITRAL or other commercial arbitration procedures, and the emergence of case-law referring to the today more than 1000 known investor-state arbitral awards and related 'annulment decisions' or national court decisions as relevant precedents, increased dramatically. The general ICSID and BIT provisions on arbitration procedures (e.g. transparency of the arbitral procedure, burden and standard of proof, multiplicity of procedures, annulment and execution) and on substantive standards (e.g. protection of good faith, reasonable expectations, non-discriminatory treatment, proportionality, due process in expropriations, fair and equitable treatment, full protection and security and of public interests of the host state, prohibitions of denial of justice and unjust enrichment, compensation also in case of indirect expropriations) leave open many specific legal questions (e.g. concerning also their relationships to WTO law, EU law, and commercial arbitration). Judicial clarification of incomplete investment treaty rules and principles (e.g. on the 'necessity' of governmental emergency measures) has become a major instrument for progressive development and adjustment of investment law. Yet, there is also widespread criticism of incoherencies among, and institutional biases in ISDS practices, for instance due to inadequate transparency and inclusiveness of arbitration procedures, conflicts of interests of commercial arbitrators acting also as advisors to TNCs, and their sometimes inadequate regard to public national and international law and jurisprudence. This need for protecting the regulatory duties of states and the public law nature of investor-state arbitration prompt ever more states to revise their BITs and related arbitration procedures (e.g. ICSID and UNCITRAL rules). The 'ordo-liberal' traditions of European economic regulation have prompted the EU to promote multilateral investment court procedures (e.g. in the EU free trade agreements with Canada and Vietnam) strengthening the public law dimensions of investment arbitration.

Due to the 'subsidiarity principle' governing social policies inside German-speaking federal and welfare states and inside the EU, the scope of multilevel protection of social rights through UN institutions (e.g. protection of labor rights by the International Labor Organization, health rights by the World Health Organization, public education by the UN Educational, Science and Cultural Organization) and of human rights through international courts and ISDS remains contested also in Europe. ${ }^{29}$ Inside the EU, also the posted workers Directive and judicial prioritization of common market freedoms over transnational exercises of trade union rights remain controversial. ${ }^{30}$ The more globalization increases the mobility of economic actors beyond state borders and transforms national into transnational PGs that no state can unilaterally protect without international law and multilevel governance institutions, the more important becomes the EU model of supplementing multilevel rights of 'market citizens' by multilevel citizenship rights and other EU fundamental rights constituting, limiting, regulating and justifying multilevel governance of PGs for the benefit of all citizens. ${ }^{31}$ As 'market justice' based on contracts and competition remains distorted by 'market failures' that risk threatening protection of 'human dignity' and human rights, 'social justice' needs to be legally constructed and protected by constitutional, legislative, administrative, judicial and international rules and institutions that are bound to differ among jurisdictions also inside common markets like the EU. GATT/WTO law (e.g. GATT Articles III, XIX-XXI) appears to have adequately protected the rights and duties of governments to protect human rights and other non-economic PGs. ${ }^{32}$ International investment law and arbitration, by

${ }^{29}$ Cf. V.Kube/E.U.Petersmann, Human Rights Law in International Investment Arbitration, in: Fontanelli/Gattini/Tanzi (eds), General Principles of Law and International Investment Arbitration (The Hague: Brill 2018), 221-268.

${ }^{30}$ Cf L.Azoulai, The Court of Justice and the Social Market Economy: The Emergence of an Ideal and the Conditions for its Realization, in: CMLRev 45 (2008), 1335-1356.

31 Cf. E.U.Petersmann, EU Citizenship as a Constitutional Restraint on the EU's Multilevel Governance of Public Goods, European Law Review 43 (2018), 89-105.

${ }^{32}$ Arguably, none of the more than 500 GATT/WTO dispute settlement rulings since 1948 has violated human rights. Yet, 'American neo-liberals', 'European ordo-liberals' and 'Chinese state-capitalists' often interpret WTO rules from different legal perspectives; cf S.Joseph/D.Kinley/J.Waincymer (eds), The WTO and Human Rights (Cheltenham: Elgar 2009); E.U. 
contrast, are increasingly criticized for insufficiently balancing protection of private investor rights with governmental duties to protect constitutional and human rights of all citizens. The Achmea judgment of the $\mathrm{CJEU}^{33}$ - according to which investor-state arbitration in relations among EU member states is inconsistent with the EU constitutional law guarantees of multilevel judicial protection of fundamental rights - illustrates the ordo-liberal, constitutional constraints of EU law on path-dependent conceptions of commercial autonomy and state sovereignty. Britain's 'Brexit' and US President Trump's 'America First mercantilism' reflect the different, utilitarian traditions of neo-liberal deregulation and poweroriented interest-group politics prevailing in many Anglo-Saxon countries.

\section{Why multilevel governance of the global economy requires multilevel constitutionalism}

Due to the strong influence of economics on the design and implementation of European and international economic law and policies, most economic lawyers use 'law \& economics methodologies', for instance in

- micro-economic price analyses of the consistency of utility-maximizing restraints of competition (by the homo economicus) with competition laws;

- macro-economic justifications of expansionary uses of limited monetary policy powers by national and European central banks;

- the allocation of property rights and legal liability for 'external effects' with due regard to transaction costs (cf. the 'Coase theorem') and 'Pareto efficiency';

- limitation of collective action problems in collective supply of global PGs confronted with 'prisoner dilemmas' (as analyzed by game theories);

- the 'optimal legal ranking' and 'separation' of trade and monetary policy instruments (e.g. in GATT/WTO law) maximizing efficient uses of scarce resources in terms of 'Kaldor-Hicks efficiency'; or

- 'public choice' analyses aimed at limiting 'rent-seeking abuses' of economic policy discretion.

German-speaking economic lawyers tend to be more influenced by 'constitutional economics' ${ }^{34}$ than by utilitarian Chicago school economists (e.g. in view of their dubious, normative premises underlying the

Petersmann, International Economic Law without Human and Constitutional Rights? Legal Methodology Questions for my Chinese Critics, in: JIEL 21 (2018), 213-231; idem, How to Reconcile Human Rights, Trade Law, Intellectual Property, Investment and Health Law? WTO Dispute Settlement Panel Upholds Australia's Plain Packaging Regulations of Tobacco Products, in: The Global Community Yearbook of International Law and Jurisprudence 2018, 69-102.

${ }^{33}$ Case C-284/16 The Slovak Republic v. Achmea BV [2018] ECLI:EU:C:2018:158.

${ }^{34}$ See, e.g., A.Steinbach/A.van Aaken, Oekonomische Analyse des Völker- und Europarechts (Tübingen: Mohr 2019). 'Constitutional economics' (as 'economic analysis of constitutional law' and of economic rights of citizens) was taught by the ordo-liberal 'Freiburg school' (e.g. of W.Eucken, F.Böhm, F.A.Hayek, V.Vanberg) and 'Virginia school' (e.g. J.Buchanan) defining economic efficiency not only in terms of 'Pareto'- and 'Kaldor-Hicks efficiency' (based on utilitarian premises), but also by (hypothetical) individual and democratic consent to inclusive, reasonable rules reconciling the interests of all affected citizens (cf. G.Brennan/J.M.Buchanan, The Reason of Rules. Constitutional Political Economy (Cambridge: CUP 1985). On the influence of ordo-liberalism and 'constitutional economics' on the 'Geneva school of law and economics' see: E.U.Petersmann, International Economic Theory and International Economic Law - On the tasks of a legal theory of international economic order, in: R.S.J.Macdonald/D.M.Johnston (eds), The Structure and Process of International Law (The Hague: Nijhoff 1983) 227-261; Q.Slobodian, Globalists. The End of Empire and the Birth of Neoliberalism (Cambridge Mass.: Harvard UP 2018), who describes the WTO as 'the paradigmatic product of Geneva School neoliberalism' (at p.25), and the 'creation of the WTO (as) a crowning victory of the neoliberal project of finding an extra-economic enforcer for the world economy in the twentieth century' (at 23). Also GATT/WTO jurisprudence (e.g. on interpreting GATT/WTO rules as protecting non-discriminatory conditions of competition) emphasized the ordo-liberal function of states and of the GATT/WTO dispute settlement systems as 'guardians of the competitive order'. 
distributive effects of 'Kaldor-Hicks efficiencies'). ${ }^{35}$ Some of the constitutional, competition and social policy principles of 'ordo-liberalism' have influenced the progressive legal construction and political legitimation of the GATT/WTO legal and dispute settlement systems, for instance in

- designing multilevel legal restraints of trade policy instruments according to their respective economic efficiency (as illustrated by Articles I-III, XI GATT, VI-IX GATS);

- separating trade and monetary policy instruments (cf. Article XV GATT, XI GATS);

- interpreting GATT/WTO market access commitments as protecting non-discriminatory conditions of competition;

- protecting and prioritizing sovereign powers to regulate and protect non-economic public goods in non-discriminatory ways (cf. Articles XIX-XXI GATT, XIV-XIVbis GATS);

- providing for legal accountability and multilevel judicial remedies limiting rule-violations and other abuses of power (e.g. in Articles X, XXIII GATT, XXIII GATS); and

- promoting progressive evolution of the incomplete GATT/WTO system through progressive legal, political and judicial clarifications and development of indeterminate GATT/WTO rules and underlying principles, in close cooperation with trade-related, other international organizations. The more than 420 WTO panel, appellate and arbitration reports (1995-2020) protecting nondiscriminatory conditions of competition and transnational rule-of-law among 164 WTO members reflect the ordo-liberal function of states and of multilevel judicial governance as 'guardians' of rules-based trade and competition.

In the current geopolitical rivalries among US President Trump's hegemonic mercantilism, Europe's multilateral ordo-liberalism and authoritarian state-capitalism (e.g. in China and Russia), 'constitutional economics' explanations of why constitutional contracts limiting 'political market failures' may be as welfare-enhancing as mutually beneficial contracts in private markets, and why 'behavioral economics' and 'political psychology' may assist in limiting 'populist abuses' of economic regulation, remain of fundamental importance for adjusting the world trading system to geopolitical rivalries and to the need for climate change mitigation. Notwithstanding Hayek's explanation of markets as spontaneous information, coordination and sanctioning mechanisms compensating the 'bounded rationality' and 'pretense of knowledge' of economic actors, ordo-liberals reject neo-liberal faith in 'free markets' and in individuals as 'rational utility-maximizers' enhancing the 'efficiency' of legal regulation. AngloSaxon conceptions of 'justice as efficiency' (e.g. rational choice under conditions of limited resources) and of counter-cyclical 'Keynesian economic interventions' are often criticized by German ordoliberals, who are inclined to regard economic problems (like monetary stability, positive interest rates rewarding private savings, necessity of public savings and austerity policies for protecting budgetary equilibria) as raising also questions of moral philosophy rather than only of utilitarian economics.

From an economic perspective, human survival and flourishing depend on supply of private goods and PGs. Private goods (like food) tend to be supplied spontaneously in private markets provided private property rights, freedom of contract and mutually agreed prices are protected and 'market failures' are legally limited. PGs (res publica) face different collective action problems if their supply is 'non-rival' (like human rights) and/or 'non-exhaustive' (like rule of law). Political and legal analyses of governance of PGs are much older than the related economic analyses since Adam Smith. After thousands of years of human experimentation with 'feudalism' (e.g. Chinese rulers justifying their authority and law by

\footnotetext{
35 See also the 'liberal paradox' criticized by A.K.Sen, The Impossibility of a Paretian Liberal, Journal of Political Economy 78 (1970) 152 (discussing situations when constitutional rules do not allocate rights regarding the distributive effects of economic rules and actions). Sen's criticism of utilitarian welfare economics ('the only things of intrinsic value for ethical calculations and evaluations of state of affairs are individual utilities') and his human 'capability approach' support the ordo-liberal priority given to human and constitutional rights empowering individuals; cf. A.K.Sen, On Ethics and Economics (Oxford: Blackwell 1987), 40, 46f: 'since the claim of utility to be the only source of value rests allegedly on identifying utility with well-being, it can be criticized both (1) on the ground that well-being is not the only thing that is valuable; (2) on the ground that utility does not adequately represent well-being', at 46.
} 
'mandates from heaven'), input-oriented 'democratic constitutionalism' (e.g. since the ancient Athenian democracy 500 years BC) and output-oriented 'republican constitutionalism' (e.g. in the city republics in ancient Rome, Florence and Venice) are recognized in democratic UN member states as the most important 'political invention' for supplying national PGs. Numerous UN conventions and UN resolutions extend constitutional principles (like human rights, rule of law and democracy) also to multilevel governance of transnational PGs. Yet, in spite of the universal recognition of human rights, rule of law and democracy as principles of UN law, many UN member states do not effectively protect these constitutional principles in their domestic legal systems; they oppose 'constitutionalization' of the law of international organizations aimed at protecting human rights and PGs more effectively. As a result, the UN, UN Specialized Agencies and the WTO often fail to protect international PGs, for instance by preventing religious, feudal or nationalist justifications of wars among or inside nations, protecting public health from the risks of toxic products (like tobacco, which killed more than 100 million human lives during the 20th century), or maintaining the WTO Appellate Body as prescribed in Article 17 of the WTO Dispute Settlement Understanding (i.e. as being 'composed of seven members', with vacancies being filled 'as they arise'). The 'constitutional approaches' elaborated by German international lawyers (as discussed in section 2) advocate limiting the powers of economic and political actors - and their 'fast rationality' in the pursuit of self-interests - by the 'slow reasonableness' of 'constitutional mindsets', for instance by empowering 'market citizens' (including not only traders and investors, but also workers and consumers) and political citizens to hold all multilevel governance agents legally, democratically and judicially more accountable for complying with multilevel human rights law and the underlying 'constitutional contracts' among citizens. German-speaking lawyers often use the examples of effective protection of multilevel rights and remedies of citizens in EU law, EEA law and under the European Convention on Human Rights (ECHR) as illustration of the advantages of providing similar, legal and judicial remedies also in other areas of IEL (e.g. using trade agreements for protecting labor rights in 'global supply chains'). The 'constitutions' (sic) establishing some UN Specialized Agencies (like the ILO, WHO, FAO and UNESCO) - which link their limited 'PGs mandates' to corresponding human rights (like labor and health rights, rights of access to food and education) - could become legally and politically more effective by empowering citizens to hold intergovernmental power politics more accountable by invoking constitutional rights and judicial remedies. Many Germanspeaking lawyers tend to support the view that - due to globalization and its transformation of national into transnational PGs - multilevel constitutionalism - as a methodology for structuring democratic selfgovernment through legislative, administrative, judicial and international institutions based on agreed 'principles of justice' and constitutional rules of a higher legal rank - offers the most coherent, legal system for protecting citizens and PGs by re-interpreting the power-oriented 'international law among states' in terms of citizen-oriented 'cosmopolitan international law', as advocated by many German legal philosophers since I. Kant. ${ }^{36}$

Law and economics analyses of the collective action problems in multilevel governance of PGs can assist in the necessary reforms of worldwide and regional governance institutions dominated by intergovernmental power politics. For instance:

- The WTO provisions on free trade areas, customs unions and other 'plurilateral' trade agreements reflect the economic insight that 'club goods' based on reciprocal membership obligations are an efficient way of reducing 'free-riding' and abuses of veto-powers in collective supply of global PGs (such as an open, rules-based world trading system) among 'coalitions of the willing'.

- The tripartite structures of ILO institutions reflect the insight that reconciliation of the competing rights and interests of labor representatives (e.g. interested in high wages), employer

\footnotetext{
${ }^{36}$ Cf. Petersmann (notes 7 and 10) and idem, EU Leadership for 'Constitutional Reforms' of International Trade and Investment Law? in: C.Corradetti/G.Sartor (eds), Global Constitutionalism without Global Democracy? in: EUI Working Papers Law 2016/21, 115-127; idem, Cosmopolitan constitutionalism: linking local engagement with international economic law and human rights, in: L.Biukovic/P.Pitman (eds), Local Engagement with International Economic Law and Human Rights (Cheltenham: Elgar 2017), 26-54.
} 
representatives (e.g. interested in low production costs) and governments (e.g. interested in 'social peace' and avoidance of costly strikes) can be promoted by inclusive bargaining, third-party mediation and judicial protection of labor rights.

- 'Differential and preferential treatment' compensating LDCs for 'positive externalities' (e.g. of protecting tropical forests and their greenhouse gas absorption capacities) and sharing of transitional adjustment costs (e.g. of moving from fossil fuels to 'green energy') may enhance global welfare.

- Public education and subsidization of 'public reason' (e.g. information on climate change and its harmful effects) may be an efficient limitation of public 'discourse failures'.

- Domestic 'governance failures' may be limited through reciprocal, multilevel commitments (e.g. competition and environmental rules protecting general consumer welfare, restrictions of toxic tobacco products) that strengthen legal and democratic accountability mechanisms, 'countervailing rights' of adversely affected citizens, and multilevel judicial remedies.

- Intergovernmental pursuit of group interests in UN/WTO governance disconnected from citizens can be countered by multilevel parliamentary and judicial involvement promoting more inclusive 'public reason', 'republican governance', and multilevel 'democratic constitutionalism'.

\section{Conclusion: Multilevel constitutionalism as a 'gentle civilizer' for a common law of humanity}

Social idealism aimed at 'civilizing' the 'international community of States' (Article 53 VCLT) has a long history in German legal philosophy, for instance in Kant's explanation of the need for cosmopolitan international law as a limitation of intergovernmental power politics by protecting equal rights of citizens in all human interactions at national, transnational and international levels of governance. ${ }^{37}$ The more globalization enables politicians and rent-seeking corporations to use foreign policy discretion for taxing and restricting domestic citizens and circumventing domestic constitutional restraints (like parliamentary and judicial control of executive trade policy powers), the stronger becomes the need for 'constitutionalizing' foreign policy powers and multilevel governance institutions. ${ }^{38}$ The plea of German-speaking emigrants - like Lauterpacht's citizen-oriented conception of international law, and his advocacy for stronger, multilevel judicial remedies of individual rights for the benefit of individuals as 'the ultimate unit and end of all law' - has been described as one successful strategy aimed at 'civilizing' and 'constitutionalizing' international law. ${ }^{39}$ Many other international law practitioners have responded to their practical experiences with intergovernmental power politics by making similar proposals for 'constitutional reforms' of international law, for instance by strengthening protection of labor rights and other human rights ${ }^{40}$ and overcoming the separation of citizen-oriented domestic law from state-centered international law. ${ }^{41}$ As the problem of controlling public power cannot be resolved

${ }^{37}$ On the relevance of Kantian legal theory for designing IEL and multilevel governance of PGs see: Petersmann (note 6), chapter 3; this book criticizes the lack of 'theories of justice' in most non-European textbooks on IEL, which often rely on neo-liberal, utilitarian and power-oriented, state-centered justifications of IEL without regard to constitutional and human rights of citizens as 'democratic principals' of governments with limited, delegated powers.

${ }^{38}$ Cf. I.Kant, Idea for a Universal History with a Cosmopolitan Purpose, in H.Reiss (ed), Kant: Political Writings (CUP 1991), at 47: 'The problem of establishing a perfect civil constitution is subordinate to the problem of a law-governed external relationship with other states, and cannot be solved unless the latter is also solved'.

${ }^{39}$ Cf. M.Koskenniemi, The Gentle Civilizer of Nations : The Rise and Fall of International Law 1870-1960 (CUP 2002).

${ }^{40}$ Cf. C.W.Jenks, The Common Law of Mankind (Praeger 1958).

${ }^{41}$ Cf. P.Allot, The Concept of International Law, in: idem, The Health of Nations: Society and Law Beyond the State (CUP 2002), at 289: 'It was a tragic day in the history of humanity when the subtle and complex concept of law was crudely split into two - national law and the law between nations'. 
without multilevel constitutional restraints of multilevel governance of PGs, it is important to recall that - during most of the history of the homo sapiens - human society, the polity and law remained unified (e.g. in ancient Greek and Roman city republics, Roman law and British common law). They became divided only when nation states and feudal rulers justified intergovernmental power politics on religious, feudal or nationalist grounds disempowering individual citizens (e.g. rulers invoking 'royal prerogatives' and international alliances exempt from domestic constitutional restraints and external legal constraints).

Multilevel constitutionalism does not pursue the illusion of an 'end of politics'; the institutionalization of 'public reason' and 'constitutional mindsets' aim at balancing and progressively clarifying the civil, political, economic, social and cultural rights of citizens and the corresponding duties of legislative, executive and judicial governance institutions to transform constitutional and human rights into PGs (such as rule of law, constitutional democracy and social welfare states protecting rights of citizens as 'agents of justice', 'constituent powers' and 'democratic principals' of multilevel governance agents with limited mandates). As the democratic preferences and legal traditions of citizens tend to differ among jurisdictions, multilevel constitutionalism must evolve bottom-up with due respect for the social reality of 'constitutional pluralism'. The creation of common markets, federal states and multilevel governance institutions in Austria, Germany and Switzerland often evolved in contextual and experimental ways rather than following a common legal logic. The history of German-speaking federal states suggests that the democratic and legal legitimacy and economic efficiency of the today global economic cooperation among $193 \mathrm{UN}$ member states, thousands of TNCs and billions of producers, traders, investors and consumers can be greatly enhanced through international agreements on 'primary rules of conduct' and 'secondary rules of recognition, change and adjudication' that ensure the overall legal consistency of the interacting private and public, national and international legal systems. In order to transform the 'law in the books' into socially effective 'law in action', multilevel rules and governance institutions must be justified and legitimized vis-à-vis citizens so that private and public actors voluntarily comply with the agreed rules.

As illustrated by the United Kingdom's 'Brexit' from the EU and by US President Trump's assault on the WTO legal and dispute settlement systems, international economic integration and related 'legal socialization' remain fragile unless they are embedded into 'constitutional contracts' supported by citizens as 'just' (in the sense of sufficiently justified with due regard to all affected interests). The creation of common markets in Germany and Switzerland in the 19th century (e.g. through the German Confederation since 1834, the German Customs Union 1834-1866 and the German Constitution of 1871, the Swiss Constitutions of 1848 and 1874) was based on progressive extension of individual liberties, property rights, non-discrimination and judicial remedies limiting the regulatory powers of the confederated states. The rights-based federal guarantees of economic freedoms (e.g. in Articles 29, 31 of the Swiss Constitution of 1874, Articles 2, 12 and 14 of the German Basic Law) protected also transnational trade with third countries and inspired the common market freedoms and judicial remedies in European economic integration law. While hegemonic nation states (like the USA and some of the BRICS countries) are likely to continue their power-oriented prioritization of 'national interests' in designing IEL, German-speaking democracies seem to have learned from European history the need for protecting 'community interests' beyond national borders, for example by protecting the civil, political, economic, social and cultural rights of their citizens as defined in European constitutional, human rights and common market law. Due to the 'paradox of liberty' (i.e. the risk of economic and political markets destroying themselves by abuses of private and public power) emphasized by German ordo-liberalism, ordo-liberal European conceptions of IEL continue to differ from 'American neo-liberalism' by their commitment to protecting the 'interdependence of social, political, economic and legal orders' and 'social justice' more comprehensively against 'regulatory capture' by powerful corporate interests and governmental violations of IEL, as they have become characteristic for US trade policies under President Trump. The US assault on the WTO dispute settlement system could entail the end of the ordo-liberal, multilevel judicial protection of transnational rule-of-law in international trade from 1995-2020. Unfortunately, the legal justifications by the Trump administration of their illegal 'blocking' of WTO 
Appellate Body (AB) nominations insist on US interpretations of WTO rules and US criticism of AB findings without any evidence that legal interpretations by the $\mathrm{AB}$ violated the customary rules of treaty interpretation or the (quasi)judicial $\mathrm{AB}$ mandate for impartial, independent and prompt third-party adjudication. The 2020 Report by the US Trade Representative criticizing the jurisprudence of the AB is distorted by legal biases and incorrect claims, ${ }^{42}$ such as

- US denial of (quasi)judicial functions of WTO third-party adjudication, even though numerous WTO publications and WTO dispute settlement reports over more than 20 years acknowledged the (quasi)judicial mandates of WTO dispute settlement bodies (e.g. WTO panel and AB reports as adopted by the DSB);

- US disregard for judicial $\mathrm{AB}$ arguments in the performance of the Dispute Settlement Understanding (DSU)'s mandate 'to clarify the existing provisions of those agreements in accordance with customary rules of interpretation of public international law' (Article 3 DSU), for instance whenever the $\mathrm{AB}$ found compliance with the time limit of 90 days (Article 17:5 DSU) which was imposed by US negotiators in 1993 notwithstanding the widespread criticism that no other court seems to be limited by such an unreasonably short time limit - impossible to reconcile with the other judicial $\mathrm{AB}$ tasks (e.g. due to illegal US blocking of the filling of $\mathrm{AB}$ vacancies);

- contradictory USTR claims that AB legal findings against the US violated the DSU prohibition to 'add or diminish the rights and obligations in the covered agreements' (Article 3:2 DSU) - even if the $\mathrm{AB}$ had justified these legal findings on the basis of the customary rules of treaty interpretation and its (quasi)judicial mandate -, notwithstanding the USTR's regular support of $\mathrm{AB}$ reports accepting 'creative WTO interpretations' advocated by the USTR as a legal complainant;

- US description of US 'zeroing practices' as a 'common-sense method of calculating the extent of dumping ${ }^{43}$ even if their biases had been consistently condemned by the AB and DSB as violations of the WTO obligations of 'fair price comparisons' (which are hardly mentioned in the USTR report);

- denigration of $\mathrm{AB}$ members as 'three unelected and unaccountable persons ${ }^{44}$ whose 'overreaching violates the basic principles of the United States Government ${ }^{45}$, notwithstanding the election of AB members through consensus decisions of 164 DSB member governments (including the USA), their (quasi)judicial mandate, and the approval of WTO agreements (including the DSU) by the US government and US Congress.

\footnotetext{
${ }^{42}$ Cf. Report on the Appellate Body of the WTO, United States Trade Representative (USTR, Washington February 2020).

43 idem, at 2 .

${ }^{44}$ idem, Introduction and pp. 8, 13.

45 idem, Introduction
} 


\section{List of references}

Adams, M./Fabbrini, F./Larouche, P. (eds), The Constitutionalization of European Budgetary Constraints (Oxford: Hart 2014)

Allot, P., The Health of Nations: Society and Law Beyond the State (Cambridge: CUP 2002)

Azoulai, L., The Court of Justice and the Social Market Economy: The Emergence of an Ideal and the Conditions for its Realization, in: CMLRev 45 (2008), 1335-1356

Baldwin, R., The Great Convergence. Information Technology and the New Globalization (Cambridge Mass.: Harvard UP 2016)

Beukers, T./De Witte, B./Kilpatrick, C. (eds), Constitutional Change Through Euro-Crisis Law (CUP 2017)

von Bogdandy, A., Constitutionalism in International Law: A Proposal from Germany, in: 47 Harvard International Law Journal (2006) 223.

Brennan, G./Buchanan, J. M., The Reason of Rules. Constitutional Political Economy (Cambridge: CUP 1985)

Commun, P., Erhards Bekehrung zum Ordoliberalismus, Freiburg Discussion Papers on Constitutional Economics 04/4 (2004)

Cottier, T./Hertig, M., The Prospects of 21st Century Constitutionalism' in: A. von Bogdandy/R.Wolfrum (eds), Max Planck Yearbook of United Nations Law (The Hague: Brill/Nijhoff 2004) 261-328

Ehm, F., Das völkerrechtliche Demokratiegebot. Eine Untersuchung zur schwindenden Wertneutralität des Völkerrechts gegenüber den staatlichen Binnenstrukturen (Tübingen: Mohr 2013).

Fassbender, B., The UN Charter as Constitution of the International Community (The Hague: M.Nijhoff 2009)

Hatzopoulos, V., From Economic Crisis to Identity Crisis: The Spoliation of EU and National Citizenships, College of Europe Research Paper in Law 01/2017

Hayek, F. A., The Road to Serfdom (London: Routledge 1944).

Hayek, F. A., The Fatal Conceit. The Errors of Socialism (University of Chicago Press 1991)

Herdegen, M., Principles of International Economic Law (Oxford: OUP 2nd ed. 2016).

Hinarejos, A., The Euro-Area Crisis in Constitutional Perspective (Oxford: OUP 2015)

Jenks, C. W., The Common Law of Mankind (Praeger 1958).

C. Joerges/E.U. Petersmann (eds), Constitutionalism, Multilevel Trade Governance and International Economic Law (Oxford: Hart 2011)

Joseph, S./Kinley, D./Waincymer, J. (eds), The WTO and Human Rights (Cheltenham: Elgar 2009)

Kennedy, E., Constitutional Faillures. Carl Schmitt in Weimar (Durham: Duke University Press 2004).

Koskenniemi, M., The Gentle Civilizer of Nations: The Rise and Fall of International Law 1870-1960 (Cambridge: CUP 2002).

Kube, V./Petersmann, E. U., Human Rights Law in International Investment Arbitration, in: Fontanelli/Gattini/Tanzi (eds), General Principles of Law and International Investment Arbitration (The Hague: Brill 2018) 
Lauterpacht, H., The Function of Law in the International Community (Clarendon Press 1933)

Mosler, H., The International Society as a Legal Community 140 Recueil des Cours (1974) 1

Müller-Armack, A., Wirtschaftsordnung und Wirtschaftspolitik. Studien und Konzepte zur Sozialen Marktwirtschaft und Europäischen Integration (Freiburg i.B. 1966)

Petersmann, E. U., International Economic Theory and International Economic Law - On the tasks of a legal theory of international economic order, in: Macdonald, R.S.J./Johnston, D. M. (eds), The Structure and Process of International Law (The Hague: Nijhoff 1983) 227-261

Petersmann, E. U., Constitutional Functions and Constitutional Problems in International Economic Law (Fribourg University/Boulder Press 1991, re-print 2020 by Routledge Publisher)

Petersmann, E. U., State Sovereignty, Popular Sovereignty and Individual Sovereignty: From Constitutional Nationalism to Multilevel Constitutionalism in International Economic Law? in: Shan, W./Simons, P./Singh, D. (eds), Redefining Sovereignty in International Economic Law (Oxford: OUP 2008), 27-60

Petersmann, E.U., International Economic Law in the 21st Century. Constitutional Pluralism and Multilevel Governance of Transnational Public Goods (Oxford: Hart 2012)

Petersmann, E.U., Multilevel Constitutionalism for Multilevel Governance of Public Goods Methodology Problems in International Law (Oxford: Bloomsbury 2017)

Petersmann, E.U., The EU's Cosmopolitan Foreign Policy Constitution and its Disregard in Transatlantic Free Trade Agreements, in: European Foreign Affairs Review 2016, 449-469

Petersmann, E.U., EU Leadership for 'Constitutional Reforms' of International Trade and Investment Law? in: C.Corradetti/G.Sartor (eds), Global Constitutionalism without Global Democracy? in: EUI Working Papers Law 2016/21, 115-127

Petersmann, E.U., Cosmopolitan constitutionalism: linking local engagement with international economic law and human rights, in: L.Biukovic/P.Pitman (eds), Local Engagement with International Economic Law and Human Rights (Cheltenham: Elgar 2017), 26-54

Petersmann, E.U., EU Citizenship as a Constitutional Restraint on the EU's Multilevel Governance of Public Goods, European Law Review 43 (2018), 89-105

Petersmann, E.U., International Economic Law without Human and Constitutional Rights? Legal Methodology Questions for my Chinese Critics, in: JIEL 21 (2018), 213-231

Petersmann, E.U., How to Reconcile Human Rights, Trade Law, Intellectual Property, Investment and Health Law? WTO Dispute Settlement Panel Upholds Australia's Plain Packaging Regulations of Tobacco Products, in: The Global Community Yearbook of International Law and Jurisprudence 2018, 69-102

Rawls, J., Political Liberalism (New York: Columbia University Press 1993)

Reiss, H. (ed), Kant: Political Writings (Cambridge: CUP 1991)

Schöbener, B./Herbst, J./Perkams, M., Internationales Wirtschaftsrecht (Heidelberg: Müller 2010).

Schwarzenberger, G., The Principles and Standards of International Economic Law, 117 Recueil des Cours (The Hague: Nijhoff 1966), 1-98

Seidl-Hohenveldern, I., International Economic Law, 198 Receuil des Cours (Nijhoff 1986), 3-264

Sen, A.K., On Ethics and Economics (Oxford: Blackwell 1987)

Simma, B., From Bilateralism to Community Interest in International Law 250 Recueil des Cours (1994) 217 
Slobodian, Q., Globalists. The End of Empire and the Birth of Neoliberalism (Cambridge Mass.: Harvard UP 2018)

Somek, A., The Cosmopolitan Constitution (Oxford: OUP 2014)

Stewart, R./Ratton Sanchez Badin, S.M., 'The WTO and Global Administrative Law' in: C., Joerges/E.U. Petersmann (eds), Constitutionalism, Multilevel Trade Governance and International Economic Law (Oxford: Hart 2011)

Tietje, C. (ed), Internationales Wirtschaftsrecht (Berlin: De Gruyter, 2009)

Vanberg, V.J., The Constitution of Markets. Essays in Political Economy (London: Routledge, 2001).

Verdross, A., Die Verfassung der Völkerrechtsgemeinschaft (Springer 1926) 
